\title{
First Nations' involvement in forest governance in Québec: The place for distinct consultation processes
}

\author{
by Stephen Wyatt ${ }^{1}$, Jean-François Fortier² Catherine Martineau-Delisle ${ }^{2}$
}

\begin{abstract}
Aboriginal peoples in Canada present a special case of citizen involvement in forest governance, with rights and status that go beyond those of other stakeholders and individuals. Increasingly, participation processes aimed specifically at Aboriginal representatives are being used to encourage their involvement in forest management. This article asks what would be the characteristics of a distinct process that could respond to Aboriginal rights, needs and expectations. We do so by combining the results of a broad Québec-wide study with those from a case study of forestry participation in a single community. A total of 68 consultation processes are analyzed. These experiences enable the identification of several characteristics of consultation processes used for First Nations. We also note that distinct consultations typically reflect the same practices that are used more generally for public participation in forestry, raising the question of whether or not these consultations truly respond to Aboriginal rights, needs and expectations in Québec.
\end{abstract}

Key words: Aboriginal peoples, Aboriginal forestry, forest management, public participation mechanisms, duty to consult, Canada

\section{RÉSUMÉ}

Étant donné leurs droits et leur statut qui se distinguent de ceux des autres parties prenantes, les Autochtones du Canada présentent un cas particulier en lien avec l'implication des citoyens dans la gouvernance des forêts. Des processus de participation s'adressant spécifiquement aux Autochtones sont progressivement mis en place afin de les impliquer davantage dans la gestion forestière. Cet article se demande en quoi les caractéristiques de processus distincts peuvent rencontrer les besoins et les attentes des Autochtones. Afin de répondre à cette question, nous présentons les résultats combinés d'une étude à grande échelle à travers le Québec et d'une étude approfondie portant sur la participation au sein d'une seule communauté autochtone. Un total de 68 processus participatifs sont analysés. Ces expériences permettent d'identifier des caractéristiques des processus participatifs utilisés avec les peuples autochtones. Elles permettent dobserver que les processus distincts reflètent généralement des pratiques communément admises pour la participation publique dans le secteur forestier. Cela soulève la question de savoir si ces processus répondent aux droits, aux besoins et aux attentes des Autochtones du Québec.

Mots clés : Autochtones, foresterie autochtone, gestion des forêts, mécanismes de participation publique, devoir de consulter, Canada

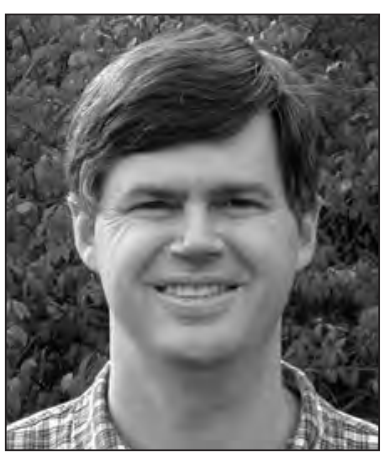

Stephen Wyatt

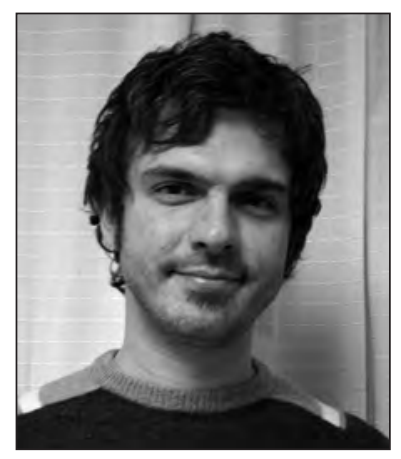

Jean-François Fortier

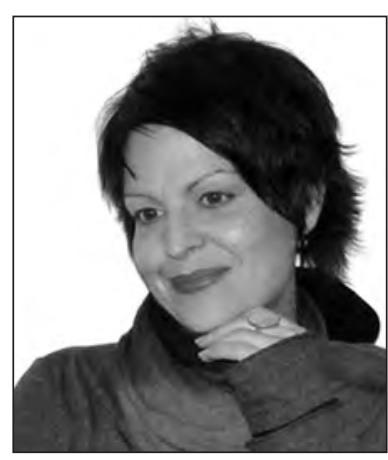

Catherine Martineau-Delisle

\footnotetext{
${ }^{1}$ Université de Moncton, campus d’Edmundston, 165 boulevard Hébert, Edmundston, New Brunswick E3V 2S8. E-mail: swyatt@umce.ca

${ }^{2}$ Doctoral student, Département de sociologie, Université Laval
} 


\section{Introduction}

Aboriginal peoples ${ }^{3}$ in Canada present a particular case in relation to citizen involvement in forest governance. Aboriginal representatives stress that they have specific legal rights that need to be recognized in consultation processes (House 1998, Natcher 2001, Newman 2009, Pesselac-Ross and Potes 2009). This means that Aboriginal peoples are "not just another stakeholder": they often expect to be consulted on the basis of "nation to nation" (Smith 1996, Stevenson and Webb 2003). There has been a growing recognition of Aboriginal rights over the last 30 years, notably as a result of conflicts, political actions and legal proceedings. In particular, jurisprudence, particularly in the Supreme Court of Canada, has established principles of Aboriginal title and consultation, clarifying the circumstances under which managers, in both government agencies and the industry, are obliged to consult with Aboriginal peoples and providing indications about how their specific rights and interests should be recognized and respected (Asch and Zlotkin 1997, McNeill 1997, House 1998, Natcher 2001, Pesselac-Ross and Potes 2009). Key elements include Calder in 1973, which recognized the legitimacy of Aboriginal claims prior to colonization, the Constitution Act of 1982, affirming Aboriginal and treaty rights, and Delgamuuk'w in 1997, which defined Aboriginal title, accepted oral evidence, and clarified consultation obligations. With the Haida and Taku River cases in 2004, both federal and provincial governments have a duty to consult and accommodate Aboriginal peoples about activities that could potentially affect their rights (Newman 2009). The Supreme Court has repeatedly stated that the outcome of the duty to consult should be negotiation leading to accommodation and reconciliation. As a result of this changing context, the federal government and many provincial governments have specific policies or legislation concerning consultation $^{4}$ of Aboriginal peoples.

Given the importance of the presence of Aboriginal peoples on forested lands in Canada, the combination of ancestral and constitutional rights has a particular meaning for the forest sector. In addition to formal/legal consultation requirements, federal and provincial governments have adopted criteria and indicators for sustainable forest management that include consultation of Aboriginal peoples (Natcher 2001, Natcher and Hickey 2002, Ross and Smith 2003, McGregor 2006, Adam and Kneeshaw 2008, Saint-Arnaud et al. 2009). Some forest certification systems require similar consultation processes (Collier et al. 2002). In sum, a variety of initiatives has been put forth to address the issue of Aboriginal involvement in forest governance.

\footnotetext{
${ }^{3}$ In Canada, the term "Aboriginal peoples" includes three indigenous groups: the First Nations, the Métis and the Inuit. In this article, we use "Aboriginal" to refer to issues and policies that are common to Aboriginal peoples across Canada, particularly in relation to rights and title. We use "First Nations" in the context of our studies in Québec to clarify that these studies do not include Métis or Inuit peoples.

${ }^{4}$ Although consultation has many shades of meaning, particularly in relation to "levels of public participation", we use the term in a broad sense, along with terms such as public participation, participatory processes or involvement mechanisms. Furthermore, the meaning of the term is not limited to that used by the Supreme Court in describing the "Duty to consult and accommodate".
}

Despite the new policies, requirements and practices related to consultation of Aboriginal communities, these approaches do not always meet Aboriginal expectations concerning their ability to control forestry practices on their traditional lands (Feit and Beaulieu 2001). If Aboriginal peoples feel that existing participatory practices are inadequate, this raises several questions. What are the characteristics of existing processes available for First Nations? What are the traits of processes that would meet their expectations and interests, while respecting their particular rights? Are processes used for Aboriginal peoples really different to those used for nonAboriginals?

In order to respond to these questions, we combined two studies that look at the involvement of First Nations in forest governance in Québec. The first study (Fortier 2007) is a large-scale examination of a wide range of First Nations' consultation processes across Québec. The second study (Wyatt 2004) is a micro-scale in-depth analysis of multiple consultation events within the Atikamekw community of Wemotaci in the Saint-Maurice region of central Québec. Together, the studies provide a critical assessment of current participatory processes for First Nations in Québec and identify characteristics of processes that are adapted to Aboriginal peoples as well as issues related to Aboriginal participation in forestrelated participatory processes. Based on the studies' results, the paper concludes with some considerations and practical suggestions for future research and policy development. Overall, the recommendations aim to support First Nations' involvement in forest governance.

\section{Consulting First Nations in Québec's Forest Sector: Requirements and Expectations}

In Canada, the federal government has authority over Aboriginal affairs while provinces are constitutionally responsible for natural resource management. Accordingly, policies and provisions for Aboriginal involvement in forest governance are different from one province to another. In Québec, First Nations did not sign historic treaties with the Crown, as was the case in most other provinces. As a result, most Nations are involved in long-running negotiations with the federal and provincial governments in order to resolve issues of rights and governance. The Cree people are an exception to this situation, having negotiated the James Bay and Northern Québec Agreement (JBNQA) in 1975 (INAC 2008) and the Paix des braves in 2002 (Gouv. du Québec 2002). These agreements establish governance arrangements that give the Cree greater influence over management of public forests. Prior to the passage of new legislation in April 2010, Québec's Forest Act provided three main mechanisms by which First Nations could contribute to forest management planning: an obligation on forest managers to invite First Nations to participate in preparing forest management plans for public lands; a process for public comments on management plans before their approval by the Ministry of Natural Resources and Wildlife (MNRW); and a provision enabling First Nations and forestry companies to modify standard harvesting rules in order to protect sites or uses of particular importance, subject to Ministry approval (Fortier 2007, Wyatt et al. 2010b). The new legislation, which has not yet entered into force, expands requirements for consultation of First Nation communities, but does not specify how this should be done. 
Forestry companies in Québec, as elsewhere in Canada, are themselves facing pressure to recognize Aboriginal concerns in forest management. In particular, forest certification systems, such as the Canadian Standards Association (CSA) and the Forest Stewardship Council (FSC), oblige companies seeking certification to consult the public and First Nations (Molnar 2003, Tollefson et al. 2007). The strongest recognition is to be found in FSC Principle 3, which states that "the legal and customary rights of indigenous peoples to own, use and manage their lands, territories, and resources shall be recognized and respected" (FSC 2004: 37). The CSA standard requires that separate consultation processes be considered for Aboriginal peoples (CSA 2002: 13).

For their part, representatives of Aboriginal people are quite clear about the need for distinct consultation processes, although they also wish to maintain the option of participating in processes that are open to the general public. Fortier (2007, 2009) analyzed 33 documents submitted by First Nations as part of three provincial consultations about the Québec forestry regime. Twenty-seven submissions contained references to how consultations should be organized, of which 14 specifically addressed the need for distinct processes. For example, the Mamuitun Nutashkuan mak Tribal Council expressed its view that "The Innu Mamuitun should not be considered at the same level as other stakeholders, i.e., those in the municipal sector in particular. We must play a leadership role and participate separately from other stakeholders at key stages of the forest management process" (Mamuitun Nutashkuan mak Tribal Council 2004: 19). Other processes' characteristics - such as preferred interaction types and need for resources (e.g., human, financial, technical) were discussed in 11 submissions.

\section{Different Forest Sector Consultation Types for Aboriginal Peoples}

Separate consultation is an element that distinguishes Aboriginal involvement from other processes for public/stakeholders consultation, where inclusiveness and broad representativeness are usually important characteristics (Rowe and Frewer 2000, Konisky and Beierle 2001, Wellstead et al. 2003). Despite the differences between Aboriginal and public involvement, existing theory and recent research on public participation provide interesting insights to inspire the development of a framework for situating participatory processes as they relate to Aboriginal peoples.

Arnstein's (1969) classic ladder of citizen participation has been modified by Berkes et al. (1991) to reflect different levels of Aboriginal power in decision-making processes, capturing First Nations' expectations regarding decision-making and the ability to control forest management. While Aboriginal demands for "meaningful consultation" (Ross and Smith 2003) may be associated with the level of power, these scales do not provide a clear moment of distinction between meaningful and meaningless. In addition, a number of studies of power-sharing arrangements have concluded that First Nations may be coopted into administration while obtaining little management responsibility (Nadasdy 2003, Rodon 2003). These observations show that formal power alone is not a sufficient indicator for Aboriginal involvement in forest governance.

Many studies looking at public participation at large (Boon and Meilby 2000, Buchy and Hoverman 2000, Konisky and Beierle 2001, Beierle and Cayford 2002) note the role of several key dimensions in the analysis of participatory processes. These include: commitment and clarity of objectives; timing and group dynamics; representativity and equity; and skills, resources and information. Within the Québec context, Lecomte et al. (2005) use similar dimensions: devolution of power; moment of participation, learning and interaction; and procedure. Importantly, Nadeau et al. (2004) and Martineau-Delisle ([In prep.]) also introduce a temporal perspective, distinguishing between temporary processes, such as single events or a short series of meetings (e.g., public hearings), and continuous processes, which provide a longer-term or more permanent mechanism for exchanging information, collaborating, and influencing decisions (e.g., an advisory committee).

In previous work (Wyatt 2004, Fortier 2007), we have noted particular characteristics of processes used for forestrelated consultations with First Nations, as distinct from those used for other stakeholders and individuals. Other work has specifically identified the need for specific consultation processes for Aboriginal people (Feit and Beaulieu 2001, Ross and Smith 2003, Stevenson and Webb 2003). Based on the insights coming from theory and research, the dimension related to the identity of participants in consultations was linked with the temporal perspective mentioned above. This led us to propose four general structures for participatory mechanisms as they relate to Aboriginal peoples (Table 1). This typology comprised of four broad types of mechanisms illustrates in a simple way the diversity of participatory processes available to Aboriginal peoples. It also allows for a high-level picture of the main types of participatory processes that are analyzed in the two studies whose results are presented in this paper.

Table 1. Four general structures for participatory mechanisms in the forest sector as they relate to Aboriginal peoples (Adapted from Nadeau et al. 2004, Martineau-Delisle [In prep.]]

How: Process type

\begin{tabular}{lcc}
\cline { 2 - 3 } Who participates: Participants & $\begin{array}{c}\text { Continuous process: } \\
\text { With permanent or long-term structure } \\
\text { (duration measured in years) }\end{array}$ & $\begin{array}{c}\text { Temporary process: } \\
\text { Ad-hoc, short-term or time specific } \\
\text { (duration measured in weeks or months) }\end{array}$ \\
\hline $\begin{array}{l}\text { Distinct process: } \\
\text { Aboriginal participants only }\end{array}$ & $\begin{array}{c}\text { Type A } \\
\text { Distinct-continuous } \\
\begin{array}{l}\text { Non-Distinct process: } \\
\text { Aboriginal and non-Aboriginal participants }\end{array}\end{array}$ & $\begin{array}{c}\text { Type B } \\
\text { Type C }\end{array}$ \\
\hline
\end{tabular}

Non-Distinct process:

Aboriginal and non-Aboriginal participants

Non-distinct-continuous

Non-distinct-temporary 
The first structure (distinct-continuous or Type A in Table 1) signifies participatory mechanisms that are restricted to Aboriginal participants and that are either permanent or long-term (with a duration measured in years) and which involve a form of ongoing collaboration between the actors involved. These often take the form of a permanent committee, with members nominated by governments and Aboriginal organizations, such as a co-management board or the James Bay Advisory Committee on the Environment. Nondistinct-continuous structures (Type B) adopt similar arrangements but are open to both Aboriginal and non-Aboriginal stakeholders or to the public. An ongoing advisory round table established under a forest certification processes is an example of such a structure. Our third general structure (Type C) is distinct-temporary where a First Nation benefits from a separate but short-term consultation, with duration measured in days, weeks or months. A common example is a discussion between a First Nation and a logging company about protection of Aboriginal sites in an annual logging plan. Fourthly, we find non-distinct and temporary processes (Type D) where First Nations, other stakeholders and often members of the public all participate in a process occurring at specific times with no ongoing collaboration. This type includes obligatory processes such as 45-day public consultation periods for forest management plans and parliamentary or independent commissions on forestry (which typically provide a limited period for public contributions).

These four structures provide a basis for integrating the results of the two studies. Within these four structures, we consider the modalities of different participatory processes, how First Nations participate in these, how these mechanisms respond to Aboriginal peoples requests and requirements for separate consultation processes, and whether or not separate processes for First Nations are really different from those used for non-Aboriginal stakeholders and individuals.

\section{Methods}

As mentioned earlier, this paper integrates the results of two studies. The first (Fortier 2007) is a large-scale study that examines the modalities of distinct and non-distinct consul- tation processes for First Nations in Québec's forestry, considering both the formal requirements and the practical experiences. In particular, the relative impact of distinct and nondistinct processes on aboriginal participation, i.e., who participates and how they intervene, is evaluated. The second study (Wyatt 2004) is a case study of multiple consultation events within the Atikamekw community of Wemotaci in the Saint-Maurice region of central Québec. The study considers the differences and similarities between different types of processes within a single social setting.

The large-scale study: Forest-related consultation processes with First Nations in cases across Québec

The large-scale study sought first to document the characteristics of distinct processes for Aboriginal participation in forest management to determine the ways in which these processes are different from others. This was done through a qualitative analysis of documentation related to the forest regime: laws (e.g., Forest Act and its revisions), policies (e.g., Consultation Policy of the MRNF), agreements (e.g., Paix des Braves, James Bay And Northern Quebec Agreement, Agreement in principle), and court decisions (e.g., Haida and Taku River cases).

Secondly, the study sought to consider the effectiveness of both distinct and non-distinct processes as they applied to First Nations. To that end, secondary data (including information on participatory processes and lists of participants) collected for a broad study of more than 700 participatory processes related to Québec's forest sector over a period of 30 years (Martineau-Delisle [In prep.]) were used. Of these 700 processes, Fortier (2007) selected those that included at least one Aboriginal participant and those for which information about participants, the modalities of participation and the types of intervention was available. This provided a sub-set of 46 processes of which 37 were non-distinct and nine were distinct (i.e., limited to First Nations and representatives from the government, or from the forestry company in the case of industry-convened processes). All 46 processes were temporary (Types $C$ and $D$ in Table 1 ) as the practical difficulties of identifying all interventions in continuous processes over a

Table 2. Number of interventions made by the various types of First Nation participants in temporary processes $(n=46$ )

\begin{tabular}{|c|c|c|}
\hline Types of First Nation participants & $\begin{array}{l}\text { Process types } \\
\text { Distinct-temporary } \\
\text { processes } \\
(\mathbf{n}=9)\end{array}$ & $\begin{array}{c}\text { Non-distinct- } \\
\text { temporary processes } \\
(n=37)\end{array}$ \\
\hline Community administrations & $31 \%(17)$ & $38 \%(84)$ \\
\hline Political organizations & $23 \%(13)$ & $36 \%(80)$ \\
\hline Consultants & $-(0)$ & $0,5 \%(1)$ \\
\hline Aboriginal forestry businesses & $7 \%(4)$ & $9 \%(20)$ \\
\hline Hunting suppliers (outfitters) & $-(0)$ & $1 \%(2)$ \\
\hline Hunter and trapper associations or individuals & $4 \%(2)$ & $-(0)$ \\
\hline Non profit and community organizations & $-(0)$ & $4(9)$ \\
\hline Coalitions (short-term alliances between individuals) & $-(0)$ & $1(3)$ \\
\hline Individuals & $18 \%(10)$ & $0.5 \%(1)$ \\
\hline Families & $-(0)$ & $0.5 \%(1)$ \\
\hline $\begin{array}{l}\text { Joint First Nations and non-Aboriginal organizations } \\
\text { (e.g., James Bay Advisory Committee on the Environment) }\end{array}$ & $16 \%(9)$ & $9 \%(20)$ \\
\hline Total & 55 interventions & 221 interventions \\
\hline
\end{tabular}


Table 3. Types of interventions used by First Nations when participating in temporary processes $(n=46$ ) (Categories adapted from Martineau-Delisle [In prep.]]

\begin{tabular}{|c|c|c|}
\hline Types of interventions used & $\begin{array}{c}\text { Process types } \\
\text { Distinct-temporary processes } \\
(\mathbf{n}=9)\end{array}$ & $\begin{array}{l}\text { Non-distinct-temporary processes } \\
\qquad(\mathbf{n}=37)\end{array}$ \\
\hline Written intervention without physical presence & $57 \%(31)$ & $37 \%(82)$ \\
\hline Formal oral intervention and physical presence & $-(0)$ & $23 \%(51)$ \\
\hline Informal oral intervention and physical presence & $43 \%(23)$ & $37 \%(83)$ \\
\hline No intervention but physical presence & $-(0)$ & $3 \%(6)$ \\
\hline Total & 54 interventions & 222 interventions \\
\hline
\end{tabular}

number of years lead to incomplete information for our types A and B. Province-wide consultations organized by the government, regional consultations and public hearings for environmental assessment are examples of processes included in the sub-set of 46 processes.

Using an approach inspired by Martineau-Delisle (2009, [In prep.]), each process was coded in relation to the profile of Aboriginal participants, the opportunities available for participation and the types of interventions used when participating. Participant lists were analyzed and Aboriginal participants were coded as belonging to one of 11 categories reflecting the type of organization that they represented, as presented in Table 2 (Fortier 2007). Participants with no organizational affiliation were coded "individual" (only 11 participants out of 276). One non-Aboriginal participant representing a band council was included and coded as "consultant". It should be noted that a single organization could have several representatives (participants) in the same process. The type of intervention used by different participants was also coded, distinguishing between formal and informal interventions and between physical presence or absence (see MartineauDelisle [In prep.]). This led to four categories of intervention: written intervention without physical presence, formal oral intervention and physical presence, informal oral presentation and physical presence, and physical presence without an intervention (see Table 3). The study did not identify whether or not a single participant made multiple interventions in a single process, such as by making frequent oral comments during consultations or submitting two separate documents.

The case study: Forestry consultation processes with the Atikamekw of Wemotaci

In order to understand the differing approaches to forest management used by First Nations and forestry companies, Wyatt (2004) undertook a case study of relations between the Atikamekw community of Wemotaci ${ }^{5}$ and companies operat-

\footnotetext{
${ }^{5}$ Wemotaci is a community of the Atikamekw people (population of 1100); an Algonquin group who have occupied the Saint-Maurice region of central Québec for approximately 4000 years (Gélinas 2000). Europeans arrived in the area in the early 1700 s, initially as fur traders and subsequently as missionaries, dam-builders and timber-cutters with logging rights being allocated to timber companies since the 1820s. The Atikamekw have continued to live and hunt in the forests of the region and, since the 1990s, have sought a greater role in contemporary management and harvesting of forest resources (Wyatt 2004, 2006).
}

ing on their traditional lands. The Wemotaci community has several different organizations with roles in forestry: the Atikamekw National Council (Conseil de la nation Atikamekw - CNA), the Wemotaci band council, a forestry services company, the "harmonization project" team and the management board of the planned Tackipoctikan sawmill (Wyatt 2006). Between January 1999 and June 2002, these organizations were involved in 22 different consultation exercises (adopting a broad definition of "consultation"). The author was an observer/participant for almost all exercises, with additional details being obtained from meeting minutes and from semi-directed interviews with organizers and with representatives of parties involved. For each exercise, a variety of information was collected. Initially, this information was coded for four characteristics: the objectives of the exercise, the mechanisms used, the identity of individual participants, and the types of information being exchanged (see Wyatt 2004 for further details).

Table 4 presents the 22 different consultation exercises at Wemotaci using the structures presented in Table $1-$ no examples of Type D (non-distinct-temporary) were observed. Distinct-temporary events (Type C) were the most common, with 11 examples. All these exercises were aimed at providing or collecting information, rather than at discussing issues or negotiating actions. Six exercises were aimed at collecting information from members of the Wemotaci community, including a survey and mapping exercises organized by the Harmonization Project and two research activities organized by the first author. Four other exercises were simply aimed at providing information (including public meetings and a newsletter), while a forum provided an opportunity for forestry companies to present their plans and respond to questions. There were 10 distinct-continuous exercises (Type A). This category was dominated by discussions about annual forest management plans, held between Harmonization Project technical specialists (both Atikamekw and nonAtikamekw) and foresters working for each of six forestry companies. Two other distinct-continuous exercises also involved community representatives and forestry companies. A community committee organized by the Harmonization project was the only distinct-continuous exercise to involve individual members of the community (Wemotaci iriniw). The sole example of a non-distinct-continuous consultation (Type B) was a Round Table organized by one of the forestry companies as part of a certification process for their operations (Côté and Bouthillier 2002), where the Harmonization Project technical team represented the Wemotaci community. 
Table 4. Types of consultation exercises at Wemotaci between January 1999 and June $2002(n=22)$

\begin{tabular}{|c|c|c|}
\hline $\begin{array}{c}\text { Distinct-continuous (A) } \\
n=10\end{array}$ & $\begin{array}{l}\text { Non-distinct-continuous (B) } \\
\qquad \mathrm{n}=1\end{array}$ & $\begin{array}{l}\text { Distinct-temporary (C) } \\
\quad \mathrm{n}=11\end{array}$ \\
\hline $\begin{array}{l}\text { - Annual planning with forestry } \\
\text { companies (6) } \\
\text { - Harmonization project advisory } \\
\text { committee with companies (1) } \\
\text { - Tackipotcikan sawmill board (1) } \\
\text { - CNA political negotiations (1) } \\
\text { - Harmonization table of community } \\
\text { members (1) }\end{array}$ & $\begin{array}{l}\text { Stakeholders' round table } \\
\text { (Table de concertation) }\end{array}$ & $\begin{array}{l}\text { - Forum for community members } \\
\text { and industry (1) } \\
\text { - Events to provide information to } \\
\text { Wemotaci iriniw (4) } \\
\text { - Events to collect information from } \\
\text { Wemotaci iriniw (6) }\end{array}$ \\
\hline
\end{tabular}

\section{Results}

Although each study was undertaken independently, the four general structures presented in Table 1 provide a basis for integrating the results of both the large-scale study and the case study. The large-scale study provides information about the characteristics of distinct mechanisms, the identity of First Nation participants in participatory processes, and the ways in which they intervened in these. The case study provides more details about the modalities of processes (objectives, information exchange, meeting dynamics and other dimensions) as they apply to the Atikamekw of Wemotaci and propose four general approaches to consultation used with this community.

\section{The provincial large-scale study}

This sub-section provides a high-level overview of forestrelated consultation mechanisms as they relate to First Nations, presenting common characteristics of some participatory processes currently available. It also explores the linkages existing between process structure type and the way First Nations participate in participatory mechanisms.

\section{Characteristics of distinct processes for First Nations}

When looking at requirements for First Nation consultation the review shows first that these frequently lead to the establishment of distinct-continuous arrangements (Type A), such as permanent committees under the JBNQA and the Paix des braves. This contrasts with the temporary processes usually available to the general public (Type D), such as public consultation processes under the Forest Act and commissions of enquiry. Together with other stakeholder groups, First Nations are also benefiting from the more recent establishment of continuous processes (Type B), such as advisory committees formed by companies seeking forest certification. Distinct-temporary processes (Type C) receive relatively little recognition in legislation and formal requirements, although the Forest Act does enable First Nations and forestry companies to negotiate "harmonization measures".

Secondly, important differences were found in timing and opportunities to contribute to forest management planning. Certain Aboriginal mechanisms, such as the Cree-Québec Forestry Council have up to 120 days to make their recommendations after receiving a management plan, compared with 45 days under the Forest Act. Furthermore, the Forest Act requires that the general public be consulted only at the end of the planning process (comments on a draft plan) while four specific groups of stakeholders (First Nations, municipalities, hunting and fishing operators and maple sugar producers) should be invited to participate earlier in the process. Furthermore, specific agreements with the Cree and the Innu nations and the Algonquin of Barrier Lake allow them even greater involvement in the planning process.

Thirdly, federal and provincial governments have recognized the lack of human and financial capacity for First Nations to participate in participatory processes and have provided assistance and resources to develop this capacity. Although there are some programs that provide for participant capacity funding, such support is more readily available to First Nations than to usual stakeholders and individuals.

Finally, the Québec government's forest-related Consultation Policy recognizes the need for distinct processes for First Nations. It specifies that consultations must be organized in collaboration with Aboriginals and adapted to their specific needs. Non-Aboriginal communities do not benefit from any equivalent targeted measures, even though some have access to funding and have a particular role in relation to participatory processes in forest management (e.g., municipal or regional organizations). The review thus demonstrates not only that distinct processes for Aboriginal peoples do exist in Québec, but also that these processes have particular characteristics that make them different from the processes available to non-Aboriginal stakeholders or to the general public (Box 1).

The following two sub-sections explore key trends in relation to the participation of First Nations in forestry consultation across Québec.

Box 1. Elements of distinct processes for Aboriginal peoples

- The processes are generally continuous rather than temporary.

- The consultation process may be jointly developed.

- A priority is given to the relationship between First Nations and the government.

- Participation throughout the planning process may be possible.

- Financial and human resources may be made available.

- More time may be available for preparing comments. 


\section{Who participates?}

The analysis of participant lists enabled us to determine exactly who from a First Nation is attending consultations (Table 2). The results reveal that community organizations (e.g., band councils) and political groups (e.g., tribal councils) are the most common participants, for both distinct and nondistinct processes. Perhaps more significant is that the diversity of Aboriginal participants was higher in non-distinct than in distinct processes, i.e., more types of groups were present in processes open to Aboriginals and non-Aboriginals. However, distinct processes lead to a much higher participation from individual members of First Nations communities, $18 \%$ of total participation as opposed to $1 \%$. These results suggest that distinct processes may be dominated by official First Nations representatives, along with some community members. However, non-distinct processes appear to be more favourable to non-official First Nations representatives, just as they are also open to non-Aboriginal stakeholders and individuals.

\section{What types of intervention are used?}

Intervention types are another important component of Aboriginal consultation practices; these may be expected to be influenced by the structure of the process (distinct or nondistinct). Table 3 provides the relative frequency of the intervention types made by First Nations in the 46 processes. In distinct processes, there is a clear division between informal oral presentations and written interventions, the later being dominant. By comparison, participants in non-distinct processes use other types of interventions, but the preference remains for informal oral interventions and written interventions. Interestingly, formal oral presentations-a format particularly common for public hearings-are abandoned in distinct processes. Overall, written interventions are privileged in both distinct (57\%) and non-distinct processes (37\%) while informal activities also constitute a preferred mode of intervention.

\section{The Atikamekw of Wemotaci case study}

The analysis of 22 consultation processes at Wemotaci enabled us to identify key differences in a series of characteristics that help distinguish between the various consultation exercises. Furthermore, the analysis allowed us to illustrate the variety of forms-grouped into four general types-in which distinct consultations for First Nations can occur.

\section{Characteristics of consultation exercises at Wemotaci}

In analysing the first of our characteristics-the goals and objectives of consultations-the analysis found that these are rarely specified in documents or plans, but can often be induced from the methods used or the information sought. Most exercises, of all three types in Table 4, were organized to obtain information on Atikamekw concerns about specific sites that should be protected during forest management operations or about more general questions associated with management practices. Several exercises were organized to provide the Atikamekw with information about proposed activities. Only one exercise, the Scierie Tackipotcikan Board, had a formal decision-making mandate, although three other committees had advisory roles.

In almost every case, each consultation exercise focused on a clear set of issues in a multi-tiered management planning process. Operational issues, as reflected in the identification of protection measures for annual logging plans, were most common, being the principle subject of annual planning meetings with forestry companies, harmonization project activities, and information events for the community. Strategic issues, such as objectives and management guidelines, were discussed in the Tackipotcikan sawmill board and to a lesser extent in the Harmonization project advisory committee and the Stakeholder round table. Political issues of access to land and the legal framework for forest management on Atikamekw traditional lands were addressed in negotiations between the CNA and federal and provincial governments. The annual meetings with forestry companies, the harmonization table, and the stakeholder round table also reviewed previous practices, demonstrating the need for monitoring as a final step in the management planning process.

Combining the goals of the consultation exercise and the issues that are treated provides an indication of the level of Atikamekw influence on forest management decision-making. Most consultation exercises were concerned with providing information about forest management operations, but managers working for forestry companies firmly retained decision-making responsibilities for these operations. Committees with an advisory mandate generally treated strategic issues, thereby enabling the Atikamekw to influence broad directions for management, although they remained excluded from decision-making. Atikamekw representatives comprised a majority of the Tackipotcikan board, and clearly had a greater influence on decisions. However, the mandate of this board was limited to business planning for the sawmill and did not extend to forest management. Political negotiations also provided a high-level of influence for the Atikamekw, but did not address strategic or operational matters of forest management.

The identity of participants in consultation exercises, as revealed by attendance lists, was most strongly related to the general structures of consultation identified in Table 1. The eleven information exercises that used a distinct-temporary type (Table 4) occurred within the community and were (unsurprisingly) dominated by members of the community. In contrast, Atikamekw participants in all continuous exercises other than the harmonization table were representatives or members of the Atikamekw technical team. Hence we use the term Wemotaci iriniw, the people of Wemotaci, to distinguish between members of the Wemotaci community and their official representatives. Wemotaci iriniw rarely participate in exercises with forest companies, although individuals may be invited to provide particular knowledge concerning an area under discussion. In particular, the ka nikanitc, the person traditionally responsible for an Atikamekw family territory, is rarely invited to contribute. Consultation exercises for strategic and political issues are dominated by representatives of the community with specialist training or experience, rather than Wemotaci iriniw, as are operational discussions with forestry companies. However, Wemotaci iriniw do participate in those exercises open to them, with 179 individuals, or $24 \%$ of the adult population of Wemotaci, attending those exercises (in the second and third columns of Table 4).

The language used varies according to the type of consultation and the parties involved. Consultations with forestry companies are held exclusively in French, are dominated by forestry jargon, and make extensive use of maps, reports and 
other printed material. In information exercises that involve only the Atikamekw, the Atikamekw language is extensively used, with one informant stating that "Atikamekw is a territorial language" and that French does not have the words to fully describe the land. In such exercises, maps and documents are often left aside, being replaced by anecdotes and stories as a way of sharing knowledge or of explaining the importance of a place or a practice. Members of the Atikamekw technical team are faced with the challenge of translating the meaning and importance of such information into forestry terminology in the French language for transmission to managers from forestry companies.

The most common location for consultation exercises is an office or conference room, with short forest visits occasionally being organized as an additional activity. Interestingly, a number of consultations aimed at Wemotaci iriniw also take this form, with exercises organized by the Atikamekw technical team resembling meetings organized with the forest industry. However, several information exercises organized by community members were held in private homes and in camps in the forest, resulting in richer discussions and greater involvement by Wemotaci iriniw.

\section{Four general consultation approaches in Wemotaci}

The analysis of consultations within a single community illustrates the variety of forms in which distinct consultations can occur (note that only one non-distinct process was present at Wemotaci). Furthermore, the 22 processes presented here can be grouped into four general types, as presented in Table 5 (Wyatt 2004). Each of these types reflects a certain consistency around the goals and objectives of a process and the choices that are made concerning who participates and how the process is organized. As compared to the categorization provided in Table 1, these four types show that distinct processes, whether continuous or temporary, can take place in very different ways. The first type, "giving and gathering of information", involves the greatest number of participants. It can contribute to a greater understanding of the questions of forest management, but rarely involves discussion about the answers. The second type is mainly used for strategic consultations to influence the directions of forest management, while the third type is appropriate for operational aspects of management such as ensuring that a particular site is protected during harvesting. Both second and third types provide opportunities for the Atikamekw to influence forest management. Nevertheless, all three first types are firmly based in the practice and science of forest management and rely upon the Atikamekw engaging management professionals to represent the community. The fourth type, "Atikamekw methods of consultation", is rarely used, but provides an alternative approach, using locations, lan- guage, and practices based in Atikamekw tradition, rather than in professional forest management. This is more familiar to Wemotaci iriniw and may be better at capturing community concerns, but so far this type has had little influence on forest management.

\section{Discussion - Key Dimensions of Consultation Processes for Aboriginal Peoples}

Both studies show that there is no single way of consulting Aboriginal peoples about forest management. The diversity of processes illustrated in this article demonstrates that both government agencies and forestry companies are prepared to seek information concerning the views and interests of Aboriginal communities, and are prepared to do so using processes that are distinct from those used for stakeholders and the public. However, a willingness to consult and a process are not, of themselves, adequate to respect Aboriginal rights or to comply with the "Duty to consult and accommodate". Nor are they necessarily effective in identifying Aboriginal concerns or in obtaining information for use in forest management plans. Using the results of both studies, covering a total of 68 consultation exercises, we identified the following keys dimensions of consultation processes for First Nations in Québec's forest sector:

- Participants targeted - use of both distinct and non-distinct processes;

- Issues addressed - existence of multiple issues for Aboriginal peoples;

- Roles for governments and forestry companies - diversity of roles;

- Extent of influence on decision-making - informing, advising or deciding;

- Aboriginal participant profile - participation by community representatives or by individuals;

- Formality of processes - language, jargon, and location. The following sub-sections consider each of these dimensions and some of the issues that they raise.

\section{Table 5. Four general approaches to distinct consultation in Wemotaci}

Type 1 - Giving and gathering of information

Discussions or activities focused on particular needs for information. Companies seek to identify specific constraints on proposed management actions. Atikamekw seek to maintain and defend their occupation and use of forest lands. Information offered by one party may not be that which is sought by the other.

\section{Type 2 - Consultation around the table} A committee or group addressing strategic issues and recommending objectives or guidelines that are implemented by others. Participants represent particular parties, often providing "expert" opinion. Meetings follow formal procedures and participants need to be sufficiently at ease to debate other experts about viewpoints and information.
Type 3 - Consultation on the map

A process that typically occurs when professional managers seek to supplement information on maps and in databanks. Atikamekw are asked to identify sites of particular importance, such as campsites or wildlife habitats, so that managers can determine appropriate means of protection. Requires familiarity with forestry maps and is not suitable for information that cannot be presented in this way.

Type 4 - Atikamekw methods of consultation Traditionally, an experienced person, the $k a$ nikantic, is responsible for each family territory. Potential users are obliged to discuss their plans with the ka nikantic, who provides comments or advice based on his/her knowledge and experience. Approval is neither sought nor given, but the suggestions of ka nikantic are usually respected. 
Participants targeted - Use of both distinct and non-distinct processes

Although Aboriginal peoples often state a preference for distinct processes, our studies show that they are also prepared to participate in consultation exercises that are open to all stakeholders and the general public. While distinct processes recognize the particular status and rights of Aboriginal peoples, they remain less common; Aboriginal communities may consider that their only opportunity to present their concerns is to participate in a non-distinct exercise. Non-distinct exercises may also provide greater opportunities for identifying common interests with other stakeholders (Fortier 2007, 2009), for developing alliances, or for influencing others.

\section{Issues addressed - Existence of multiple issues for Aboriginal peoples}

Aboriginal peoples have particular status and rights and often seek to express these in consultation processes for forest management, along with their preferences for particular harvesting practices and the identification of specific sites or values that need to be protected. However, most consultation exercises are limited to a single set of issues, as reflected in the mandate or goals of the exercise as commonly established by the government or a forestry company (Wyatt 2004). Political processes bring together representatives of Aboriginal communities and governments in negotiations around land rights and forest governance, usually in a distinct and continuous process. Processes at the strategic level address issues such as management goals or general types of harvesting practices and involve Aboriginal peoples and representatives from government agencies, forestry companies and possibly other stakeholders. These processes show the greatest variation and may be distinct or non-distinct and temporary or continuous, but typically take the form of a structured meeting of representatives of the parties, often around a table in a conference room. Operational questions are often discussed in distinct processes as foresters and First Nations' representatives meet to evaluate various options for management activities or for protection of particular forest values and uses, often using maps. Meetings of this type may become more organized and frequent, moving from temporary ad hoc processes to continuous mechanisms. In fact, we noted that participants in processes at all levels (political, strategic and operational) spoke of a need for continuity to ensure that consultations lead to concrete results. This suggests a fourth level of consultation, that of monitoring and evaluation of results in the forest.

Roles for government and forestry companies - Diversity of roles Throughout the processes analyzed, we note that the role of governments and forestry companies varies, depending upon the level of consultation and the issues being discussed. Government involvement is essential at the political level where rights and governance issues are being discussed and forestry company involvement would usually be inappropriate. Strategic discussions may require the participation of both government and company representatives to address issues, possibly with the inclusion of other stakeholders, while operational matters are typically left to forestry companies in Québec. Monitoring and evaluation may again require the participation of all parties.

We also observed a sense of frustration in interventions by
Aboriginal representatives in many consultation exercises. They felt that important issues such as rights or governance were being ignored in consultation exercises with forestry companies, in favour of more specific questions of forest harvesting practices or protection measures. This may demonstrate that the roles of governments and forestry companies, along with the level of the issues under discussion, are being confused (Wyatt et al. 2010a). Parties responsible for organizing consultation exercises need to be clear about the mandate of the process, and governments need to ensure that political issues (such as Aboriginal rights) are addressed in order to avoid these impinging upon strategic and operational consultations about forest management.

\section{Extent of influence in forest decision-making - Informing, advis- ing or deciding}

It must be noted that none of the 68 processes discussed in the two studies provide First Nations with an opportunity for direct participation in forest decision-making. Instead, they allow Aboriginal representatives to attempt to influence decisions by providing information and by expressing their concerns and interests. If First Nations wish to have a direct role in decision-making for their traditional lands, as is claimed in many negotiation and consultation processes, then it appears unlikely that existing consultation exercises will meet this expectation. In fact, there are a number of examples of mechanisms for such a role in Québec (Wyatt et al. 2010b), notably through co-management arrangements (Rodon 2003) and with the Cree (LaRusic 1995, Feit and Beaulieu 2001, Rynard 2001) and the Algonquin of Barrier Lake (Notzke 1994). However, these cases are few when compared with the large number of non-decisional processes, as illustrated by the two studies presented here and in other studies (Nadeau et al. 2004, Martineau-Delisle and Nadeau 2010). Only a few cases among the 693 forest-related public participation processes identified in the last three decades or so in the Québec forest sector have formal power over decision-making (MartineauDelisle [In prep.]).

In terms of Arnstein's (1969) ladder, most processes are in the middle range, representing "degrees of tokenism". However, it does appear that positive experience with processes for providing information (low on Arnstein's ladder) may help the parties to establish processes such as advisory round tables, which are higher on the ladder. Nevertheless, a separate study of the stakeholder round table involving the Wemotaci Atikamekw (Côté and Bouthillier 2002) found that this process contributed to sharing information but did not alter basic decision-making roles. Similarly, Feit and Beaulieu (2001) concluded that existing participation processes did not satisfy Cree expectations and that consultation was, in fact, mainly aimed at legitimizing government and industry practices. For many First Nations, Aboriginal rights may raise expectations of a decision-making role for forest lands, going beyond the current obligations established by the "duty to consult and accommodate" and requiring something more than simply providing information or advice. Martineau-Delisle and Nadeau (this issue) observed similar expectations among non-Aboriginal participants in consultation processes. In this regard, the Wemotaci experience demonstrates that distinct consultations, whether temporary or continuous, are not sufficient to guarantee a direct role in decision-making related to forest management. 


\section{Aboriginal participant profile - Participation by community rep-} resentatives or by individuals

Aboriginal presence in consultation exercises is typically as an official representative, such as a band councillor or an employee with technical expertise, regardless of whether these are distinct or non-distinct processes. The Aboriginal public, such as Wemotaci iriniw, or specific Aboriginal interested parties, such as business operators or hunters and trappers, are rarely present. A number of factors may contribute to this. First Nation expectations of "nation-to-nation" consultations imply that these will be undertaken by duly nominated representatives of each group. Concepts of Aboriginal rights and the duty to consult are usually interpreted as applying to Aboriginal communities collectively, rather than to individuals. Furthermore, the technical nature of most forest management consultation processes is biased towards technical personnel, typically employed by community or national councils. Nevertheless, the fact that Aboriginal participation is more diversified in non-distinct than in distinct processes (Table 2) suggests that the Aboriginal public seeks to contribute to forest issues. Similarly, high participation rates of Wemotaci iriniw in events within the community highlight the interest of this public in events that are organized in appropriate ways. Other studies of participants in consultations (Martineau-Delisle 2009, [In prep.]) also show that representatives of parties and/or organizations are in the majority, rather than the public or citizen, whether Aboriginal or non-Aboriginal.

\section{Formality of processes - Language, jargon and location}

The great majority of consultation exercises examined adopted fairly formal processes with procedures for presentations or submissions, structured discussions and defined outputs. They were also typically held in dedicated meeting rooms or offices of key participants and were almost exclusively in French. Among the exercises described in the first study, proportionally, more informal interventions were observed in distinct than in non-distinct processes. The nondistinct processes had a higher proportion of formal written interventions, but also showed greater diversity in the forms of interventions. Distinct processes at both strategic and operational levels frequently involve the use of maps and specific terminology associated with forest management. Such formality in presenting information can also prove to be a barrier for Aboriginal people. At the level of a single community, formal structures were most common, although a small number of exercises aimed at Wemotaci iriniw adopted a different approach, with the use of the Atikamekw language, meetings in various locations and non-formal meeting structures. This was associated with a much higher rate of participation of the Aboriginal public, including women, and a broader range of issues and information being discussed.

Martineau-Delisle ([In prep.]) notes that many participatory practices are defined following a formal or conventional approach, while alternative forms are simply not considered (either not implemented or, when implemented, not regarded as formal enough to be considered as participatory practices). This bias can lead to technocratic processes that act to enhance the contributions of some groups while excluding those of others. For example, Martineau-Delisle (2009) shows that, while First Nations are among the participant groups that have grown the most over the last decades in forest- related participatory process in Québec, they still hold a marginal place as compared to other stakeholders. For First Nations, traditional approaches to managing peoples' actions on land, such as the role of $k a$ nikantic at Wemotaci, do not necessarily fit the accepted understanding of consultation. Although alternative approaches are being developed, such as the Ndoho Istchee system proposed by the Waswanipi Model Forest (WCMF 2007), this type of approach remains the exception. Most consultation processes for First Nations remain firmly wedded to a non-Aboriginal conception of "consultation".

\section{Conclusion}

In Canada, Aboriginal peoples have particular rights and are able to claim a special status in relation to forest governance. Forestry agencies in governments across the country have been seeking ways to accommodate Aboriginal rights and to provide processes that meet obligations to consult with Aboriginal peoples (Wyatt et al. 2010a). We have concentrated on the case of Québec and have presented two complementary studies; a broad comparison of practices across the province and an in-depth analysis of practices within a single community. Together, these studies lead to three important conclusions for First Nations, for governments, and for forestry companies.

Firstly, none of the processes analyzed provide for direct participation in decision-making for forest management, although they do enable varying degrees of influence on such decisions. If a decision-making role is a key objective of First Nations, as is often stated in submissions to various participatory processes, then it may be expected that they will continue to demand new or modified processes in the hope of attaining a decision-making role consistent with their expectations. Alternatively, First Nations may choose to withdraw from existing processes, arguing that these do not respect their rights and status. Either situation appears to contribute to instability in forest governance.

Secondly, this review of 68 consultation exercises shows that their characteristics typically reflect commonly accepted practices for public participation in forest governance, even when Aboriginal people contribute to designing these. If consultation processes are distinct in name rather than in practice, then it is questionable as to whether these really enable First Nations to present their priorities, understanding, and objectives for the management of forest lands. The question is not just do distinct consultation processes exist for First Nations, but how can these processes reflect the rights and interests of Aboriginal people as well as the diversity of their communities? New forestry legislation enacted by Québec in April 2010 contains specific provisions for consulting First Nations (Wyatt et al. 2010b), but it remains to be seen how this will be implemented in practice and whether existing approaches to consultation will be maintained or modified.

Thirdly, First Nations' engagement in forest governance should be seen as a number of juxtaposed processes. We consider that the diversity of issues associated with forest management and government, along with the existence of different levels of consultation, means that no single process could meet all needs. It appears that First Nations recognize this and that they are using a series of processes to meet their various objectives or expectations. Multiple processes also imply a variety of techniques and the ability to adapt these to the 
needs of different types of participants. We consider that multiple processes are a positive feature, although we recognize that these make additional demands upon human and financial resources, especially for First Nations themselves.

These conclusions raise many additional questions and suggest several hypotheses for future research. Are lower numbers of distinct processes (as compared to non-distinct) simply due to fewer opportunities or do other factors contribute? Is the principle of "nation-to-nation" consultations the only reason for relatively low participation of the Aboriginal public in consultation processes? What differences (in techniques and in results) can be observed between processes developed with Aboriginal involvement and those without such a contribution? What is the relative value of continuous processes when compared with temporary ones? Further research to respond to these questions would be most useful to First Nations, governments and forestry companies who are seeking appropriate ways to consult with Aboriginal peoples and to accommodate their interests.

In this regard, it is possible to imagine processes of consultation inspired by traditional Aboriginal approaches, including the use of traditional language or terminology, oral communications in place of written submissions and maps, and meetings in the forest rather than in conference rooms. Such an approach may lead to higher or to more effective participation by individual members of First Nations. However, citizen involvement in forest governance in Québec appears dominated by a more conventional and formal approach to consultation, with few opportunities for alternative techniques. Interestingly, an alternative model could also help in designing processes allowing for a greater diversity of participants (Martineau-Delisle 2009).

Although our discussion has focused on First Nations experiences in forest governance in Québec, we consider that these raise some important issues for designing consultation processes for non-indigenous groups. In particular, we note the importance of recognizing the specific characteristics of different stakeholders groups and individuals, and of planning particular mechanisms to address these where necessary. As illustrated by Québec First Nations, a "distinct" process may require innovative approaches to crafting structures and activities for target populations, rather than simply organizing a separate meeting.

In undertaking this study, we sought to gain a deeper understanding of characteristics of existing processes available for First Nations, of the ways by which First Nations participate in forest governance in Québec, and to identify characteristics of consultation processes that could respond to their expectations, recognizing their particular rights and status. We also aimed to determine if the characteristics of distinct processes used for Aboriginal peoples were different from those usually associated with non-distinct forest-related participatory processes. The characteristics presented in the discussion section are not so much techniques or elements of a successful consultation process as they are factors that need to be considered when preparing processes or policies for consulting First Nations. Our study has not found any processes that meet all expectations, and, in fact, we consider it unlikely that such a process could exist. Instead, First Nations, governments and the forest industry (and even other parties) will need to develop specific consultation processes that take account of the goals and expectations of each party.
The factors presented here, and other similar experiences to be observed across Canada, may help to find effective ways of engaging Aboriginal peoples in forest governance.

\section{Acknowledgements}

We would like to thank the many people who provided information and insights that made this study possible, especially members of the Atikamekw community of Wemotaci who welcomed Stephen Wyatt over several years. Most of the work for the two studies presented here was carried out while the authors were students at Université Laval and we would like to thank the multiple contributions of Louis Guay, Luc Bouthillier and Sylvie Poirier in guiding us. Finally, our work benefited from the financial support of a number of organizations including the Social Sciences and Humanities Research Council, the Sustainable Forest Management Network, Natural Resources Canada (Canadian Forest Service),the Fonds québécois de la recherche sur la société et la culture et the Fonds québécois de la recherche sur la nature et les technologies.

\section{References}

Adam, M.C. and D. Kneeshaw. 2008. Local level criteria and indicator frameworks: A tool used to assess aboriginal forest ecosystem values. Forest Ecology and Management 255(7): 2024-2037.

Arnstein, S.R. 1969. A ladder of citizen participation. American Institute of Planning Journal 35(2): 216-224.

Asch, M. and N. Zlotkin. 1997. Affirming Aboriginal titles: A new basis for comprehensive claims negotiations. In M. Asch (ed.). Aboriginal and treaty rights in Canada: Essays on law, equity, and respect for difference. pp. 208-229. UBC Press, Vancouver, BC.

Beierle, T. and J. Cayford. 2002. Democracy in Practice: Public Participation in Environmental Decisions. Resources for the Future, Washington, DC. 149 p.

Berkes, F., P. George and R.J. Preston. 1991. Co-management: The Evolution in Theory and Practice of the Joint Administration of Living Resources. Alternatives 18(2): 12-18.

Boon, T.E. and H. Meilby. 2000. Enhancing public participation in state forest management: a user council survey. Forestry 73: 155-164.

Buchy, M. and S. Hoverman. 2000. Understanding public participation in forest planning: a review. Forest Policy and Economics 1: $15-25$.

[CSA] Canadian Standards Association. 2002. CSA Standard Z809-02, Sustainable forest management: Requirements and guidance. Canadian Standards Association, Mississauga, ON. 78 p. Available at http://www.csa-international.org/product_areas/forest_ products_marking/program_documents/CAN_CSA_Z80902O_English.pdf [Accessed 25 August 2010].

Collier, R., B. Parfitt and D. Woollard. 2002. A Voice on the land: An Indigenous Peoples' Guide to Forest Certification in Canada. National Aboriginal Forestry Association and Ecotrust Canada, Ottawa and Vancouver, Canada. 106 p.

Côté, M.-A. and L. Bouthillier. 2002. Assessing the effect of public involvement processes in forest management in Quebec. Forest Policy and Economics 4: 213-225.

Feit, H.A. and R. Beaulieu. 2001. Voices from a disappearing forest: Government, corporate and Cree participatory forestry management practices. In C.H. Scott (ed.). Aboriginal Autonomy and development in northern Québec and Labrador. pp. 119-148. UBC Press, Vancouver, BC.

[FSC] Forest Stewardship Council. 2004. National Boreal Standard. Available at http://www.fsccanada.org/docs/39146450 F65AB88C.pdf [accessed 24 August 2009]. 
Fortier, J.-F. 2007. Premières Nations, mécanismes de participation et gestion des forêts : Étude comparative des méthodes, des discours et des pratiques, Mémoire de maîtrise, Département de sociologie, Université Laval, Québec, QC. 159 p.

Fortier, J.-F. 2009. Aboriginal opinions about the consultation processes in forest management in Québec. Sustainable Forest Management Network. Research Notes Series. Edmonton, AB. 6 p.

Gélinas, C. 2000. La gestion de l'étranger: Les Atikamekw et la présence eurocanadienne en Haute-Mauricie 1760-1870. Septentrion, Québec, QC. 378 p.

Gouv. du Québec. 2002. Entente concernant une nouvelle relation entre le Gouvernement du Québec et les Cris du Québec. Available at http://www.autochtones.gouv.qc.ca/relations_autochtones/ententes/ cris/entente_cris_20020207.pdf [Accessed 17 September 2009].

House, R.D. 1998. Aboriginal claims and the forest industry: Claims processes and recent developments in the courts. The Forestry Chronicle 74(3): 334-342.

[INAC] Indian and Northern Affairs Canada. 2008. Treaties with Aboriginal people in Canada. Available at http://www.aincinac.gc.ca/al/ldc/ccl/tra-eng.asp [Accessed 17 September 2009].

Konisky, D.M. and T.C. Beierle. 2001. Innovations in Public Participation and Environmental Decision Making: Examples from the Great Lakes Region. Society \& Natural Resources 14(9): 815-826.

LaRusic, I.E. 1995. Managing Mishtuk: The experience of Waswanipi band in developing and managing a forestry company. In P.D. Elias (ed.). Northern Aboriginal Communities: Economics and Development. pp. 53-87. Captus Press, North York, ON.

Lecomte, N., C. Martineau-Delisle and S. Nadeau. 2005. Participatory requirements in forest management planning in Eastern Canada: A temporal and interprovincial perspective. The Forestry Chronicle 81(3): 398-402.

Mamuitun Nutashkuan mak Tribal Council. 2004. Mémoire du conseil tribal Mamuitun mak Nutashkuan, Présenté à la commission d’étude sur la gestion de la forêt publique québécoise, 14 juin 2004. Available at http://www.commission-foret.qc.ca/memoires/doc 209_09_Mamuitun.pdf [Accessed 17 September 2009].

Martineau-Delisle, C. 2009. Les acteurs de la participation publique à la gestion des forêts : Pluralisme sélectif ou universel? In 77e Congrès de l'Acfas, Ottawa.

Martineau-Delisle, C. [In prep]. Un changement de gouvernance en forêt? La participation publique à la gestion forestière québécoise : évolution, impacts et participants. Thèse de doctorat. Faculté des sciences sociales, Université Laval, Québec, QC.

Martineau-Delisle, C. and S. Nadeau. 2010. Assessing the Effects of Public Participation Processes from the Point of View of Participants: Significance, Achievements, and Challenges. The Forestry Chronicle 86(6): 753-765.

McGregor, D. 2006. La participation autochtone à l'aménagement durable des forêts en Ontario: des avancées vers la coopération. Recherches amérindiennes au Québec 36(2-3): 61-70.

McNeill, K. 1997. The meaning of Aboriginal title. In M. Asch (ed.). Aboriginal treaty rights in Canada: Essays on law, equity, and respect for difference. pp. 135-154. UBC Press, Vancouver, BC.

Molnar, A. 2003. Forest Certification and Communities: Looking forward to the Next Decade. Forest Trends, Washington, DC. 65 p. Nadasdy, P. 2003. Hunters and Bureaucrats: Power, Knowledge, and Aboriginal-State Relations in the Southwest Yukon. UBC Press, Vancouver, BC. 328 p.

Nadeau, S., C. Martineau and J.-F. Fortier. 2004. Enquête sur la participation publique à la gestion des forêts dans certaines régions du Québec. Commission détude sur la gestion de la forêt publique québécoise. Rapport de mandat de recherche externe. Québec, QC. 82 p. Natcher, D. 2001. Land use research and the duty to consult: a misrepresentation of the Aboriginal landscape. Land Use Policy 18(2): $113-122$.
Natcher, D. and C. Hickey. 2002. Putting the community back into community-based resource management: A criteria and indicators approach to sustainability. Human Organization 61(4): 350-363.

Newman, D.G. 2009. The duty to consult: new relationships with Aboriginal peoples. Purich Publishing, Saskatoon, SK. 127 p.

Notzke, C. 1994. Aboriginal peoples and natural resources in Canada. Captus Press, North York, ON. 352 p.

Pesselac-Ross, M. and V. Potes. 2009. Treaty 8 land-based rights: A legal and ethical analysis. In M. Stevenson and D. Natcher (eds.). Changing the Culture of Forestry in Canada: Engaging Canada's Aboriginal Peoples in Sustainable Forest Management. pp. 181-196. CCI Press, Edmonton, AB.

Rodon, T. 2003. En partenariat avec l'État; Les expériences de cogestion des Autochtones du Canada. Les Presses de l'Université Laval, Québec, QC. 320 p.

Ross, M.M. and P. Smith 2003. Meaningful Consultation with Indigenous Peoples on Forest Management in Canada. In XII World Forestry Congress, Québec, QC.

Rowe, G. and L.J. Frewer. 2000. Public participation methods: A framework for evaluation. Science, Technology \& Human Values 251: 3-29.

Rynard, P. 2001. Ally or colonizer? The federal state, the Cree Nation and the James Bay Agreement. Journal of Canadian Studies - Revue détudes canadiennes 36(2): 8-48.

Saint-Arnaud, M., H. Asselin, C. Dubé, Y. Croteau and P. Charlie. 2009. Developing criteria and indicators for Aboriginal forestry: mutual learning through collaborative research. In M. Stevenson and D. Natcher (eds.). Changing the Culture of Forestry in Canada: Engaging Canada's Aboriginal Peoples in Sustainable Forest Management. pp. 85-106. CCI Press, Edmonton, AB.

Smith, P. 1996. Aboriginal participation in forest management: Not just another "stakeholder". The Forestry Chronicle 72(1): 2-5.

Stevenson, M. and J. Webb. 2003. Just another stakeholder? First Nations and sustainable forest management in Canada' boreal forest. Chapter 3. In P.J. Burton, C. Messier, D.W. Smith and W.L. Adamowicz. Towards sustainable management of the boreal forest. pp. 65-112. NRC Research Press, Ottawa.

Tollefson, C., F. Gale and D. Haley. 2007. Setting the Standard: Certification, Governance and the Forest Stewardship Council. UBC Press, Vancouver, BC. 404 p.

[WCMF] Waswanipi Cree Model Forest. 2007. Ndoho Istchee: An innovative approach to aboriginal participation in forest management planning. Waswanipi Cree Model Forest, Waswanipi, Québec. $141 \mathrm{p}$.

Wellstead, A.M., R.C. Stedman and J.R. Parkins. 2003. Understanding the concept of representation within the context of local forest management decision making. Forest Policy and Economics 5(1): $1-11$

Wyatt, S. 2004. Co-existence of Atikamekw and industrial forestry paradigms: Occupation and management of forestlands in the StMaurice river basin, Québec. $\mathrm{PhD}$ thesis. Université Laval. Université Laval, Québec, QC. $376 \mathrm{p}+$ xiv.

Wyatt, S. 2006. «Si les autres le font, pourquoi pas nous? » La quête des Atikamekw de Wemotaci pour un rôle dans la foresterie au Nitaskinan. Recherches amérindiennes de Québec 36(2-3): 9-18.

Wyatt, S., J.-F. Fortier, G. Greskiw, M. Hébert, D. Natcher, S. Nadeau, P. Smith and R. Trosper. 2010a. Collaboration between Aboriginal peoples and the Canadian forestry industry: a dynamic relationship. A State of Knowledge report. Sustainable Forest Management Network. Edmonton, AB.

Wyatt, S., J.-F. Fortier and M. Hebert. 2010b. Collaboration entre Autochtones et autres acteurs forestiers du Québec : portrait d'une diversité de pratiques et de modèles. The Forestry Chronicle 86(2): 243-255. 